\title{
PENGARUH KOMPONEN CITRA MEREK (BRAND IMAGE) TERHADAP LOYALITAS KONSUMEN PRODUK MINUMAN SHARE TEA DI KOTA MANADO
}

\author{
Gabriella Susana Tineke Ransulangi \\ Nordy F.L. Waney \\ Joachim N.K. Dumai
}

\begin{abstract}
ABSRACT
This study aims to determine the influence of brand image on consumer loyalty Share Tea drink in the city of Manado. In its development, bubble tea drinks into today's drinks with a variety of flavor variants that can attract consumers in all ages. Reach back the market that has declined, and to maintain the market it has gained is a challenge that Share Tea companies must face in creating consumer loyalty. This study uses data obtained from questionnaires, observations and direct interviews with the manager of Tea Share in Manado City. The analysis technique used is multiple regressions. From this research can be concluded that Components of brand image consisting of coorporate image, user image, and product image has a influence on Consumer Loyalty. The components of the brand image together have a positive influence on consumer loyalty. The coorporate image and user image individually does not significantly affect consumer loyalty, while product image individually has a significant effect on consumer loyalty.
\end{abstract}

Keywords: brand image, consumer loyalty, Share Tea, Manado City

\begin{abstract}
ABSTRAK
Penelitian ini bertujuan untuk mengetahui pengaruh citra merek (brand image) terhadap loyalitas konsumen minuman Share Tea di Kota Manado. Dalam perkembangannya, minuman bubble tea menjadi minuman masa kini dengan berbagai varian rasa sehingga dapat menarik konsumen diberbagai kalangan usia. Meraih kembali pasar yang telah menurun, dan untuk mempertahankan pasar yang telah diperolehnya adalah tantangan yang harus dihadapi perusahaan Share Tea dalam menciptakan loyalitas konsumen. Penelitian ini menggunakan Data yang diperoleh dari kuesioner, observasi serta wawancara langsung dengan pihak manajer Share Tea di Kota Manado. Teknik analisis yang digunakan adalah regresi berganda. Dari penelitian ini dapat disimpulkan bahwa Komponen citra merek yang terdiri dari citra pembuat, citra pemakai, dan citra produk berpengaruh sebesar 40,4 persen terhadap Loyalitas Konsumen. Komponen citra merek secara bersama-sama memiliki pengaruh yang positif terhadap variabel loyalitas konsumen. Citra pembuat dan citra pemakai secara individu tidak berpengaruh secara signifikan terhadap loyalitas konsumen, sedangkan citra produk secara individu berpengaruh signifikan terhadap loyalitas konsumen.
\end{abstract}

Kata kunci: citra merek, loyalitas konsumen, Share Tea, Kota Manado 


\section{PENDAHULUAN}

\section{Latar Belakang}

Kemajuan teknologi menciptakan persaingan antar industri yang semakin ketat, dilihat dari semakin banyaknya perusahaan dengan berbagai inovasi produk.Kondisi ini menuntut semua perusahaan untuk lebih unggul dalam menawarkan produk kepada konsumen. Persaingan tersebut menciptakan sulitnya perusahaan untuk mendapat dan mempertahankan jumlah konsumen yang loyal. Perusahaan harus mempertimbangkan strategi mulai dari konsep, sasaran, pengembangan bisnis, implementasi, hingga evaluasi yang akan dijalankan. Penyusunan strategi-strategi tersebut bertujuan untuk menempatkan produknya pada posisi teratas, serta menciptakan konsumen yang loyal. Dalam menciptakan konsumen yang loyal, perusahaan harus dapat meningkatkan citra merek (brand image) produk mereka.Tanpa citra merek yang kuat dan positif, sangatlah sulit bagi perusahaan untuk menarik pelanggan baru dan mempertahankan yang sudah ada (Ismani dalam Rizan, 2012). Industri minuman berbahan dasar produk pertanian di Indonesia mengalami perkembangan, salah satunya di Kota Manado. Munculnya berbagai jenis minuman dengan tampilan dan rasa yang unik menarik para konsumen dari berbagai usia. Salah satu perusahaan industri minuman yang memiliki potensi pasar yaitu Share Tea. Share Tea merupakan salah satu perusahaan sekaligus merek produk minuman bubble tea yang mendunia. Bubble tea itu sendiri adalah minuman yang berbahan dasar teh dengan dikombinasikan berbagai varian rasa serta diberikan isian (topping) berupa jelly atau sejenisnya (Manasaputri, 2015).

Dalam perkembangannya, minuman bubble tea menjadi minuman masa kini dengan berbagai varian rasa sehingga dapat menarik konsumen diberbagai kalangan usia. Share Tea juga menyediakan tempat bagi konsumen untuk duduk bersantai sambil menikmati segarnya Share Tea. Hal tersebut mendorong anak muda untuk mengunjungi outlet Share Tea. Share Tea pertama kali membuka cabang outletnya di Kota Manado pada tahun 2013 di
Manado Town Square 1 dan sampai saat ini Share Tea telah memiliki 3 Outlet di daerah Manado. Dalam perkembangannya, tingkat penjualan Share Tea mengalami pasang surut. Meraih kembali pasar yang telah menurun, dan untuk mempertahankan pasar yang telah diperolehnya adalah tantangan yang harus dihadapi. Dalam kasus ini, penting bagi pemasar untuk membangun citra merek dalam upaya mencapai loyalitas konsumen. Sesuai dengan uraian diatas maka peneliti mengambil judul "Pengaruh Komponen Citra Merek (Brand Image) Terhadap Loyalitas Konsumen Produk Minuman Share Tea Di Kota Manado".

\section{Perumusan Masalah}

Berdasarkan latar belakang, maka permasalahan yang muncul adalah Apakah komponen citra merek (brand image) yaitu Citra pembuat, Citra pemakai dan Citra produk berpengaruh positif terhadap loyalitas konsumen produk minuman Share Tea di Kota Manado?

\section{Tujuan dan Manfaat Penelitian}

Tujuan dari penelitian ini adalah untuk mengetahui seberapa kuat pengaruh komponen citra merek (Brand Image) produk minuman Share Tea terhadap Loyalitas Konsumen di Kota Manado. Manfaat dari penelitian ini adalah memberikan masukan bagi perusahaan mengenai strategi pemasaran, terutama dalam menciptakan citra merek yang kuat dalam mencapai loyalitas konsumen serta menambah wawasan dan referensi bagi penelitian selanjutnya.

\section{METODE PENELITIAN}

\section{Waktu dan Tempat Penelitian}

Penelitian ini dilaksanakan di tiga cabang Outlet Share Tea yaitu di Manado Town Square 1, Manado Town Square 3, dan IT Center Manado. Penelitian ini berlangsung selama tiga bulan mulai dari bulan Maret hingga bulan Mei 2017.

Jenis dan Sumber Data

Sumber data yang digunakan dalam penelitian ini adalah data primer dan data sekunder. Data primer adalah data yang diperoleh langsung dari 
wawancara dengan menggunakan kuisioner, sedangkan data sekunder adalah data yang diperoleh dari perusahaan Share Tea, buku dan jurnal.

\section{Metode Pengambilan Sampel}

Penelitian ini menggunakan teknik pengambilan sampel teknik sampling tidak acak (nonprobability sampling) dengan cara purposive sampling (sampling dengan tujuan). Pengambilan sampel dibagi menjadi dua bagian yaitu di hari kerja (Weekdays) dan akhir pekan (Weekend). Hari kerja diwakili oleh hari Rabu dan akhir pekan diwakili oleh hari Sabtu. Sampel pada hari Rabu sebanyak 20 sampel dan hari Sabtu sebanyak 20 Sampel.

\section{Konsep Pengukuran Variabel \\ 1. Skala Likert}

Skala likert adalah teknik pengukuran sikap yang paling luas digunakan dalam riset pemasaran. Uji skala likert memungkinkan responden menjawab dalam berbagai tingkatan pada setiap butir pertanyaan sebagai berikut :
Skor $1=$ Tidak Setuju (TS)
Skor $2=$ Kurang Setuju $(\mathrm{KS})$
Skor $3=\operatorname{Netral}(\mathrm{N})$
Skor $4=$ Cukup Setuju (CS)
Skor $5=$ Sangat Setuju (SS)

\section{Citra Pembuat ( Variabel $I_{c}$ )}

Citra Pembuat (Corporate Image), mencakup:

1.) Citra perusahaan Share Tea.

2.) Citra logo perusahaan Share Tea.

3.) Jaringan penjualan Share Tea.

4.) Layanan perusahaan Share Tea.

\section{Citra Pemakai (Variabel $\mathrm{I}_{\mathrm{u}}$ )}

Citra Pemakai (User Image), mencakup:

1.) Kepercayaan diri konsumen Share Tea.

2.) Harapan konsumen Share Tea.

3.) Keyakinan konsumen Share Tea bahwa produk tersebut dapat terus bersaing dengan produk lain.

4. Citra Produk (Variabel $\mathrm{I}_{\mathrm{p}}$ ) Citra Produk (Product Image), mencakup:

1.) Merek produk Share Tea mudah diingat konsumen.

2.) Slogan produk Share Tea.

3.) Desain kemasan produk Share Tea.

4.) Ukuran produk Share Tea yang disediakan.

5.) Harga produk Share Tea.

\section{Loyalitas Konsumen (Variabel $\mathrm{L}_{\mathrm{c}}$ )} Loyalitas Konsumen, mencakup:
1.) Kepuasan yang dirasakan konsumen Share Tea.

2.) Ketertarikan konsumen untuk mengkonsumsi produk Share Tea kembali.

3.) Kesediaan konsumen dalam memperkenalkan produk Share Tea terhadap orang lain.

4.) Kesediaan konsumen untuk mengajak orang lain untuk mengkonsumsi produk Share Tea.

5.) Konsumen tidak memiliki keinginan untuk berpindah ke merek produk yang sejenis.

\section{Uji Validitas}

\section{Uji Instrumen}

Uji Validitas merupakan uji untuk mengetahui valid atau tidaknya instrumen atau variabel.

\section{Uji Reliabilitas}

Dalam kuantitatif, suatu data dinyatakan reliabel apabila dua atau lebih peneliti dalam obyek yang sama menghasilkan data yang sama, atau sekelompok data bila dipecah menjadi dua menunjukkan data yang tidak berbeda. (Sugiyono dalam Umar, 2000).

\section{Teknik Analisis Data}

\section{Analisis Regresi Linear Berganda}

Analisis regresi linear berganda digunakan untuk mengetahui pengaruh variabel bebas terhadap variabel terikat.Model persamaan yang digunakan dalam penelitian ini sebagai berikut:

Keterangan :

$$
\mathbf{L}_{\mathrm{c}}=\mathbf{a}+\mathbf{b}_{1} \mathbf{I}_{\mathrm{c}}+\mathbf{b}_{2} \mathbf{I}_{\mathrm{u}}+\mathbf{b}_{3} \mathbf{I}_{\mathrm{p}}+\mathbf{e}
$$

$\mathrm{L}_{\mathrm{c}}$ : Loyalitas konsumen / Loyalty Consumer (variabel terikat)

$I_{c}$ : Citra Perusahaan / Corporate Image (variabel bebas).

$\mathrm{I}_{\mathrm{u}}$ : Citra Pemakai / User Image (variabel bebas).

$\mathrm{I}_{\mathrm{p}}$ : Citra Produk / Product Image (variabel bebas).

a : Nilai konstan atau tetap, yang merupakan ratarata nilai $\mathrm{L}_{\mathrm{c}}$ pada

saat nilai $I_{c}, I_{u}$, dan $I_{p}$ sama dengan nol.

b1 : Koefisien regresi parsial, mengukur rata-rata nilai $\mathrm{L}_{\mathrm{c}}$ untuk tiap perubahan $\mathrm{I}_{\mathrm{c}}$ dengan menganggap $\mathrm{I}_{\mathrm{u}}$ dan $\mathrm{I}_{\mathrm{p}}$ konstan.

b2 : Koefisien regresi parsial, mengukur rata-rata nilai $\mathrm{L}_{\mathrm{c}}$ untuk tiap perubahan $\mathrm{I}_{\mathrm{u}}$ dengan menganggap $\mathrm{I}_{\mathrm{c}}$ dan $\mathrm{I}_{\mathrm{p}}$ konstan.

b3 : Koefisien regresi parsial, mengukur rata-rata nilai $L_{c}$ untuk tiap perubahan $I_{p}$ dengan menganggap $\mathrm{I}_{\mathrm{c}}$ dan $\mathrm{I}_{\mathrm{u}}$ konstan.

e : Standar error. 


\section{Uji Hipotesis}

\section{1.) Koefisien Determinasi $\left(\mathbf{R}^{2}\right)$}

Koefisien determinasi digunakan untuk mengetahui tinggi rendahnya pengaruh suatu variabel.

\section{2.) Uji Simultan (Uji F)}

Uji simultan (Uji F) ini dilakukan untuk mengetahui apakah variabel bebas secara serempak mempunyai pengaruh yang signifikan terhadap variabel terikat.

\section{3.) Uji Parsial (Uji T)}

Pengujian hipotesis ini dilakukan menggunakan analisis regresi untuk mengetahui pengaruh variabel independen secara individual.

\section{HASIL DAN PEMBAHASAN}

\section{Gambaran Umum Lokasi Penelitian}

\section{Sejarah Perusahaan}

Share Tea awalnya berdiri di Taiwan pada tahun 1992. Berawal dari sebuah kepercayaan yang terbina, Share Tea telah berdiri kurang lebih 180 branch yang tersebar diluar negara taiwan. Share Tea digagaskan pada bulan Mei 2012 di Jakarta, Indonesia dengan mengambil branch international dari Taiwan sebagai unit bisnis dari KINO GROUP COMPANIES. Bulan September 2012, outlet Share Tea pertama kali dibuka di Plaza Semanggi, Jakarta. Pengembangan Share Tea akan di arahkan kepada "stand-alone sites" di beberapa kawasan pusat perkantoran dan seterusnya untuk pengembangan di beberapa kota di luar Jakarta. Pengembangan Share Tea dengan sistem waralaba yang telah dipersiapkan akan mempercepat keberadaan Share Tea di area Jakarta dan kota kota lain di seluruh Indonesia salah satunya di Kota Manado. Share Tea adalah jawaban dari sebuah pertanyaan di kalangan kelas menengah yang mencari sebuah alternatif tempat untuk melepaskan dahaga yang bertaraf internasional, mempunyai kualitasterbaik di seluruh dunia dengan harga terjangkau yang dapat dikunjungi setiap saat.
Share Tea memiliki visi dan misi serta nilainilai perusahaan, sebagai berikut:

Visi : Beverages Outlet International yang besar dan tersebar di seluruh indonesia.

Misi :

1. Memperkenalkan Minuman Tea dengan kualitas terbaik di dunia.

2. Menyajikan minuman tea dan tapioka pearl dengan kelas internationaldan menciptakan branch image yang baik di Indonesia.

3. Memberikan pelayanan dengan setulus hati dan higienis.

4. Meningkatkan kesejahteraan seluruh karyawan dan stake holder.

Nilai Nilai Perusahaan :

1. Integritas,

2. Antuisias,

3. Inovatif,

4. Kekeluargaan,

5. Profesionalisme,

6. Semangat,

7. Responsif,

8. Tolong menolong,

9. Komitmen,

10. Bekerja cerdas,

11. Saling menghormati,

12. Terus belajar dan Peduli.

\section{Lokasi Penjualan Share Tea di Kota Manado}

Share Tea memiliki tiga cabang outlet di Kota Manado yang masing-masing bertempat di Manado Town Square 1 lantai 1, IT Center lantai 1, dan Manado Town Square 3 lantai 3. Tiga cabang outlet Share Tea tersebut memiliki varian produk yang sama. Selain minuman, Share Tea juga menyediakan makanan pendamping seperti kentang goreng, dimsum, dll. Dari ketiga cabang outlet Share Tea di Kota Manado, outlet Share Tea Manado Town Square 3 memiliki konsumen dengan jumlah terbanyak dari dua cabang outlet Share Tea lainnya. Hal tersebut dipengaruhi oleh ramainya pengunjung Mall, serta klasifikasi pengunjungnya yaitu pengunjung kelas menengah keatas.

\section{Varian Produk Share Tea}

Share Tea memiliki beberapa varian produk yang dapat dinikmati di outlet Share Tea sesuai 
dengan selera masing-masing. Varian-varian produk Share Tea adalah sebagai berikut:

1. Brewed Tea

2. Coffee

3. Fresh Milk

4. Fruit Tea

5. Yakult

6. Ice Cream

7. Taiwanese Dessert

8. Milk Tea

9. Rocksalt \& Cheese

10. Smoothies

11. Snack

Selain minuman dan makanan pendamping, Share Tea juga menyediakan Topping yang dapat dicampur kedalam minuman pilihan sesuai dengan selera konsumen.

\section{Karakteristik Responden}

Responden dalam penelitian ini merupakan konsumen produk minuman Share Tea yang ditemui di outlet Share Tea sebanyak 40 orang. Karakteristik responden yang dimasukkan dalam penelitian yaitu berdasarkan jenis kelamin, kelompok usia, jenis pekerjaan, pendapatan, dan frekuensi berkunjung.

\section{Jumlah Responden berdasarkan Jenis Kelamin}

Pengelompokkan responden berdasarkan jenis kelamin dilakukan untuk mengetahui seberapa banyak konsumen dengan jenis kelamin laki-laki dan perempuan yang ditemui di outlet Share Tea. Pengelompokkan responden berdasarkan jenis kelamin dapat dilihat pada Tabel 1.

Tabel 1. Jumlah Responden berdasarkan Jenis Kelamin

\begin{tabular}{ccc}
\hline Jenis Kelamin & $\begin{array}{c}\text { Jumlah } \\
\text { Responden }\end{array}$ & $\begin{array}{c}\text { Persentase } \\
(\%)\end{array}$ \\
\hline Laki-laki & 8 & 20 \\
Perempuan & 32 & 80 \\
\hline Total & 40 & 100 \\
\hline
\end{tabular}

Tabel 1 menunjukkan bahwa, konsumen dengan jenis kelamin perempuan lebih banyak ditemui di outlet Share Tea dengan persentase sebesar 80 persen dibandingkan dengan konsumen berjenis kelamin laki-laki. Jenis kelamin perempuan lebih banyak ditemui karena sambil mengkonsumsi Share Tea konsumen perempuan bisa berkumpul sambil berbagi cerita.

\section{Jumlah Responden berdasarkan Kelompok Usia}

Pengelompokkan responden berdasarkan kelompok usia dilakukan untuk mengetahui konsumen dengan kelompok usia mana yang paling banyak ditemui di outlet Share Tea. Pengelompokkan responden berdasarkan kelompok usia dapat dilihat pada Tabel 2.

Tabel 2. Jumlah Responden berdasarkan Kelompok Usia

\begin{tabular}{ccc}
\hline Usia & $\begin{array}{c}\text { Jumlah } \\
\text { Responden }\end{array}$ & $\begin{array}{c}\text { Persentase } \\
(\%)\end{array}$ \\
\hline 13-23 tahun & 32 & 80 \\
24-34 tahun & 7 & 17,5 \\
35-45 tahun & 0 & 0 \\
45> tahun & 1 & 2,5 \\
\hline Total & 40 & 100 \\
\hline
\end{tabular}

Tabel 2 menunjukkan bahwa, konsumen Share Tea didominasi oleh konsumen umur antara 13-23 tahun, selanjutnya konsumen dengan umur antara 24-34 tahun dan konsumen dengan umur 45 tahun keatas sebesar 2,5 persen. Varian rasa Share Tea yang beragam sangat menarik konsumen di berbagai usia terutama di kalangan remaja yang menyukai minuman dengan cita rasa yang cenderung manis.

\section{Jumlah Responden berdasarkan Jenis Pekerjaan}

Pengelompokkan responden berdasarkan jenis pekerjaan dilakukan untuk mengetahui konsumen dengan jenis pekerjaan mana yang paling banyak ditemui di outlet Share Tea. Pengelompokkan responden berdasarkan jenis pekerjaan dapat dilihat pada Tabel 3.

Tabel 3. Jumlah Responden berdasarkan Jenis Pekerjaan

\begin{tabular}{lcc}
\hline Jenis Pekerjaan & $\begin{array}{c}\text { Jumlah } \\
\text { Responden }\end{array}$ & $\begin{array}{c}\text { Persentase } \\
(\%)\end{array}$ \\
\hline Pelajar/Mahasiswa & 32 & 80 \\
PNS & 1 & 2,5 \\
Swasta & 5 & 12,5 \\
Wiraswasta & 2 & 5 \\
Tidak Bekerja & 1 & 2,5 \\
\hline Total & 40 & 100 \\
\hline
\end{tabular}


Tabel 3 menunjukkan bahwa, konsumen Share Tea yang paling banyak adalah pelajar/mahasiswa, kemudian pegawai swasta, selanjutnya pegawai wiraswasta, diikuti PNS dan konsumen yang tidak bekerja dengan persentase masin-masing 2,5 persen. Faktor utama yang menjadikan konsumen pelajar/mahasiswa sebagai konsumen terbanyak karena konsumen Share Tea yang memang didominasi oleh konsumen remaja.

\section{Jumlah Responden berdasarkan Pendapatan /Uang Saku}

Pengelompokkan responden berdasarkan jenis kelamin dilakukan untuk mengetahui konsumen dengan pendapatan/uang saku berapa yang paling banyak ditemui di outlet Share Tea. Pengelompokkan responden berdasarkan pendapatan/uang saku dapat dilihat pada Tabel 4.

\section{Tabel 4. Jumlah Responden berdasarkan Pendapatan /Uang Saku}

\begin{tabular}{ccc}
\hline $\begin{array}{c}\text { Pendapatan/ } \\
\text { Uang Saku }\end{array}$ & $\begin{array}{c}\text { Jumlah } \\
\text { Responden }\end{array}$ & $\begin{array}{c}\text { Persentas } \\
\mathrm{e}(\%)\end{array}$ \\
\hline$<1.000 .000$ & 29 & 72,5 \\
$1.000 .000-2.000 .000$ & 4 & 10 \\
$2.000 .001-3.000 .000$ & 4 & 10 \\
$3.000 .000>$ & 3 & 7,5 \\
\hline Total & 40 & 100 \\
\hline
\end{tabular}

Tabel 4 menunjukkan bahwa, konsumen Share Tea yang berpendapatan dibawah 1 juta rupiah adalah konsumen yang paling banyak dengan persentase sebesar 72,5 persen, diikuti konsumen Share Tea yang berpendapatan antara 1 juta-2 juta rupiah dan konsumen Share Tea yang berpendapatan antara 2 juta-3 juta rupiah masing-masing sebesar 10 persen, selanjutnya konsumen Share Tea yang berpendapatan lebih dari 3 juta rupiah. Banyaknya konsumen Share Tea dengan pendapatan/uang saku dibawah 1 juta rupiah didukung oleh rendahnya pendapatan/uang saku konsumen pelajar/mahasiswa.

\section{Jumlah Responden berdasarkan Frekuensi Berkunjung}

Pengelompokkan responden berdasarkan jenis kelamin dilakukan untuk mengetahui konsumen dengan berapa frekuensi berkunjung yang paling banyak ditemui di outlet Share Tea. Pengelompokkan responden berdasarkan frekuensi berkunjung dapat dilihat pada Tabel 5.

Tabel 5. Jumlah Responden berdasarkan Frekuensi Berkunjung

\begin{tabular}{lcc}
\hline $\begin{array}{l}\text { Frekuensi } \\
\text { Berkunjung }\end{array}$ & $\begin{array}{c}\text { Jumlah } \\
\text { Responden }\end{array}$ & $\begin{array}{c}\text { Persentase } \\
(\%)\end{array}$ \\
\hline 1-2 kali & 9 & 22,5 \\
3-4 kali & 11 & 27,5 \\
5-6 kali & 5 & 12,5 \\
6> kali & 15 & 37,5 \\
\hline Total & 40 & 100 \\
\hline
\end{tabular}

Tabel 5 menunjukkan bahwa, kebanyakan konsumen Share Tea sudah pernah berkunjung di outlet Share Tea lebih dari 6 kali. Selanjutnya konsumen Share Tea dengan frekuensi berkunjung 3-4 kali, diikuti konsumen Share Tea dengan frekuensi berkunjung 1-2 kali dan konsumen Share Tea dengan frekuensi berkunjung 5-6 kali. Hasil tersebut menunjukkan bahwa, kebanyakan konsumen Share Tea yang ditemui telah beberapa kali mengunjungi serta mengkonsumsi Share Tea. Alasan konsumen sering berkunjung ke outlet Share Tea karena Share Tea menyediakan sofa dan meja yang dapat digunakan untuk bersantai, serta didukung oleh suasana outlet yang bersih dan nyaman.

\section{Uji Instrumen}

\section{Uji Validitas}

Uji Validitas merupakan uji untuk mengetahui valid atau tidaknya instrumen atau variabel. Tabel 6 berikut hasil pengujian validitas:

Tabel 6 menunjukkan bahwa seluruh item pertanyaan yang digunakan dalam penelitian ini memiliki nilai $r$ hitung yang lebih besar dari $r$ tabel untuk total sampel 40 orang. Hasil tersebut menyatakan bahwa seluruh item pertanyaan yang digunakan adalah valid atau dapat mengukur apa yang seharusnya diukur dalam penelitian ini. 
Tabel 6. Hasil Pengujian Validitas

\begin{tabular}{|c|c|c|c|c|}
\hline No. & Variabel & $\mathrm{r}$ hitung & $r$ tabel & Keterangan \\
\hline 1 & $\begin{array}{l}\text { A. Citra } \\
\text { Pembuat } \\
\mathrm{I}_{\mathrm{c}} \cdot 1 \\
\mathrm{I}_{\mathrm{I}} \cdot 2 \\
\mathrm{I}_{\mathrm{c}} \cdot 3 \\
\mathrm{I}_{\mathrm{c}} \cdot 4\end{array}$ & $\begin{array}{l}0,463 \\
0,574 \\
0,500 \\
0,590\end{array}$ & $\begin{array}{l}0,312 \\
0,312 \\
0,312 \\
0,312\end{array}$ & $\begin{array}{l}\text { Valid } \\
\text { Valid } \\
\text { Valid } \\
\text { Valid }\end{array}$ \\
\hline 2 & $\begin{array}{l}\text { B. Citra } \\
\text { Pemakai } \\
\mathrm{I}_{\mathrm{u}} \cdot 1 \\
\mathrm{I}_{\mathrm{u}} \cdot 2 \\
\mathrm{I}_{\mathrm{u}} \cdot 3 \\
\end{array}$ & $\begin{array}{l}0,567 \\
0,361 \\
0,335\end{array}$ & $\begin{array}{l}0,312 \\
0,312 \\
0,312\end{array}$ & $\begin{array}{l}\text { Valid } \\
\text { Valid } \\
\text { Valid }\end{array}$ \\
\hline 3 & $\begin{array}{l}\text { C. Citra Produk } \\
\mathrm{I}_{\mathrm{p}} \cdot 1 \\
\mathrm{I}_{\mathrm{p}} \cdot 2 \\
\mathrm{I}_{\mathrm{p}} \cdot 3 \\
\mathrm{I}_{\mathrm{p}} \cdot 4 \\
\mathrm{I}_{\mathrm{p}} \cdot 5\end{array}$ & $\begin{array}{l}0,420 \\
0,441 \\
0,455 \\
0,469 \\
0,365\end{array}$ & $\begin{array}{l}0,312 \\
0,312 \\
0,312 \\
0,312 \\
0,312\end{array}$ & $\begin{array}{l}\text { Valid } \\
\text { Valid } \\
\text { Valid } \\
\text { Valid } \\
\text { Valid }\end{array}$ \\
\hline 4 & $\begin{array}{l}\text { D. Loyalitas } \\
\text { Konsumen } \\
\mathrm{L}_{\mathrm{c}} \cdot 1 \\
\mathrm{~L}_{\mathrm{c}} \cdot 2 \\
\mathrm{~L}_{\mathrm{c}} \cdot 3 \\
\mathrm{~L}_{\mathrm{c}} \cdot 4 \\
\mathrm{~L}_{\mathrm{c}} \cdot 5\end{array}$ & $\begin{array}{l}0,342 \\
0,370 \\
0,484 \\
0,372 \\
0,332\end{array}$ & $\begin{array}{l}0,312 \\
0,312 \\
0,312 \\
0,312 \\
0,312\end{array}$ & $\begin{array}{l}\text { Valid } \\
\text { Valid } \\
\text { Valid } \\
\text { Valid } \\
\text { Valid }\end{array}$ \\
\hline
\end{tabular}

\section{Uji Reliabilitas}

Uji reliabilitas dilakukan untuk mengetahui konsistensi alat ukur, apakah alat ukur yang digunakan dapat diandalkan dan dipercaya serta tetap konsisten jika pengukuran tersebut diulang. Tabel 7 berikut hasil pengujian reliabilitas:

Tabel 7. Hasil Pengujian Reliabilitas

\begin{tabular}{lcc}
\hline Variabel & Alpha & Keterangan \\
\hline Citra Pembuat $\left(\mathrm{I}_{\mathrm{c}}\right)$ & 0,666 & Reliabel \\
Citra Pemakai $\left(\mathrm{I}_{\mathrm{u}}\right)$ & 0,614 & Reliabel \\
Citra Produk $\left(\mathrm{I}_{\mathrm{p}}\right)$ & 0,606 & Reliabel \\
Loyalitas Konsumen $\left(\mathrm{L}_{\mathrm{c}}\right)$ & 0,609 & Reliabel \\
\hline
\end{tabular}

Tabel 7 menunjukkan bahwa seluruh variabel yang digunakan dalam penelitian ini memiliki nilai Alpha Cronbach lebih dari 0,60. Hasil tersebut menyatakan bahwa seluruh variabel yang digunakan dalam penelitian ini Reliabel atau konsisten.

\section{Pengaruh Komponen Citra Merek (Brand} Image) Terhadap Loyalitas Konsumen Share Tea

\section{Uji Hipotesis}

\section{Koefisien Determinasi $\left(\mathbf{R}^{\mathbf{2}}\right)$}

Koefisien determinasi digunakan untuk mengetahui tinggi rendahnya pengaruh suatu variabel.Dari hasil perhitungan diketahui bahwa, koefisien determinasi (Adjusted $R$ Square) yang diperoleh sebesar 0,404. Hal ini berarti 40,4 persen loyalitas konsumen dapat dijelaskan oleh variabel Citra Pembuat, Citra Pemakai, dan Citra Produk, sedangkan sisanya yaitu 59,6 persen Loyalitas Konsumen dipengaruhi oleh variabelvariabel lainnya yang tidak diteliti dalam penelitian ini.

\section{Uji Simultan (Uji F)}

Uji simultan (Uji F) ini dilakukan untuk mengetahui apakah variabel bebas secara serempak mempunyai pengaruh yang signifikan terhadap variabel terikat. Hasil pengujian simultan (Uji F) menunjukkan nilai f-hitung sebesar 9,822 lebih besar dari nilai f-tabel 2,86 dengan nilai signifikansi (sig) sebesar 0,00. Nilai signifikansi jauh lebih kecil dari 0,05 maka model regresi dapat digunakan untuk memprediksi loyalitas konsumen atau dapat dikatakan bahwa Citra Pembuat, Citra Pemakai, Dan Citra Produk secara bersama-sama berpengaruh terhadap Loyalitas Konsumen.

\section{Uji Parsial (Uji T)}

Uji Parsial (Uji T) dilakukan untuk mengetahui pengaruh masing-masing atau secara parsial variabel bebas yaitu Citra Pembuat, Citra Pemakai, dan Citra Produk terhadap variabel dependen yaitu Loyalitas Konsumen. Hasil pengujian Uji T menunjukkan bahwa nilai probabilitas Citra Pembuat dan Citra Pemakai lebih besar dari 0,05 yang berarti Citra Pembuat dan Citra Pemakai secara individu tidak berpengaruh secara signifikan terhadap Loyalitas Konsumen. Citra Produk memiliki nilai probabilitas yang jauh lebih kecil dari 0,05 yang berarti bahwa Citra Produk secara individu berpengaruh signifikan terhadap Loyalitas Konsumen. Citra Produk menunjukkan nilai t-hitung sebesar 3,283 dan koefisien regresi sebesar 0,523 serta nilai probabilitas sebesar 0,002 lebih kecil dari 0,05 yang berarti bahwa Citra Produk berpengaruh signifikan terhadap Loyalitas Konsumen. Tidak berpengaruh signifikannya Citra Pembuat dan Citra Pemakai dipengaruhi oleh kurangnya pengetahuan produk (product knowledge) dari perusahaan terhadap konsumen sehingga konsumen kurang mengetahui manfaat dari produk Share Tea itu sendiri. 


\section{Analisis Regresi Linear Berganda}

Analisis regresi linear berganda digunakan untuk mengetahui pengaruh variabel bebas terhadap variabel terikat. Hasil model persamaan regresi linear berganda dalam penelitian ini, sebagai berikut:

$$
L_{c}=\mathbf{5 , 8 1 7}+\mathbf{0 , 5 2 3} I_{p}
$$

Koefisien regresi Citra Produksebesar 0,523 memberikan arti bahwa Citra Produk berpengaruh positif terhadap loyalitas konsumen untuk mengkonsumsi produk minuman Share Tea. Dari hasil model persamaan regresi diatas, dapat dikatakan bahwa dengan memberi pengetahuan produk kepada konsumen Share Tea, meningkatkan dan mempertahankan kualitas produk yang sesuai dengan harga yang diberikan maka konsumen Share Tea yang loyal akan bertambah.

\section{KESIMPULAN DAN SARAN}

\section{Kesimpulan}

Komponen citra merek yang terdiri atas Citra Pembuat, Citra Pemakai, dan Citra Produk berpengaruh lemah terhadap Loyalitas Konsumen Share Tea. Komponen citra merek secara simultan memiliki pengaruh yang positif terhadap variabel Loyalitas Konsumen Share Tea. Secara parsial Citra Pembuat dan Citra Pemakai tidak berpengaruh secara signifikan terhadap Loyalitas Konsumen Share Tea, sedangkan Citra Produk berpengaruh signifikan terhadap Loyalitas Konsumen Share Tea.

\section{Saran}

Saran yang dapat diajukan berdasarkan kesimpulan diatas, yaitu: Perusahaan Share Tea harus memenuhi harapan konsumen dengan memberikan brosur yang berisi tentang pengenalan dan manfaat produk Share Tea, Mempertimbangkan pengembangan jaringan outlet di beberapa kawasan perbelanjaan untuk meningkatkan Citra Pembuat dan Citra Pemakai, Perusahaan harus meningkatkan dan mempertahankan kualitas produk serta mempertimbangkan berbagai promosi untuk meningkatkan daya tarik beli konsumen untuk meningkatkan Citra Produk, Perusahaan Share Tea juga dianjurkan untuk mempertimbangkan kembali sloganShare Tea yang sekarang karena berdasarkan pengamatan peneliti sebagian besar konsumen tidak mengetahui slogan dari Share Tea.

\section{DAFTAR PUSTAKA}

Budi, H. 2013. Pengaruh Kualitas Produk Terhadap Kepuasan, Reputasi Merek Dan Loyalitas Konsumen Jamu Tolak Angin PT. Sido Muncul. Jurnal Manajemen Teori dan Terapan.

Diab, B. 2009. Analisis Pengaruh Nilai Pelanggan Dan Citra Merek Terhadap Kepuasan Pelanggan Dalam Meningkatkan Retensi Pelanggan (Studi Kasus Pada Gies Batik Pekalongan). Doctoral dissertation, program Pascasarjana Universitas Diponegoro.

Kusno, F., Radityani, A., \& Kristanti, M. 2007. Analisa hubungan brand strategy yang dilakukan Goota Japar rcoal Grill and Café dan brand rang sudah diterima konsumen. Jurnal Manajemen Perhotelan.

Marlina, L., \& Danica, C. 2009. Analisis pengaruh cash position, debt to equity ratio, dan return on assets terhadap dividend payout ratio. Jurnal Manajemen Bisnis.

Manasaputri Sri Autami, N. L. M., \& Suasana, I. 2015. Pengaruh Retail Mix Terhadap Keputusan Pembelian Konsumen Pada Gerai Chatime. E-Jurnal Manajemen Universitas Udayana.

Muhammad, I. 2012. Strategi Pemasaran Untuk Membangun Citra Dan Loyalitas Merek. Survey Pada Pelanggan Provider Seluler GSM Prabayar Telkomsel, Indosat, dan XL di Makassar. IPB Press, Bogor

Prawitasari, S. Y., \& Pamungkas, O. 2011. Analisis Swot Sebagai Dasar Perumusan Strategi Pemasaran Berdaya Saing (Studi Pada Dealer Honda Tunggul Sakti di Semarang). Doctoral dissertation, Universitas Diponegoro.

Rizan, M., Saidani, B., \& Sari, Y. 2012. Pengaruh brand image dan brand trust terhadap brand loyalty Teh Botol Sosro. Jurnal Riset Manajemen Sains Indonesia (JRMSI).

Saputra, F. 2007. Pengaruh environmental performance dan environmental disclosure terhadap economic performance.

Susanto, A.B \& Wijarnako, H. 2004. Power branding: Membangun Merek Unggul Dan Organisasi Pendukungnya. Mizan Pustaka. Bandung.

Umar, H. 2000. Metodologi Penelitian. Gramedia Pustaka Umum, Jakarta. 